\title{
INTUSSUSCEPTION ASSOCIATED WITH SAND ACCUMULATION IN A GREATER RHEA (RHEA AMERICANA)
}

\author{
Jael Soares BATISTA, Moacir Franco de OLIVEIRA, Tiago da Silva TEÓFILO, \\ Ana Caroline Freitas Caetano de SOUSA, Wanderson Lucas Alves dos SANTOS, \\ Igor Renno Guimarães LOPES, Ana Indira Bezerra Barros GADELHA, Moisés \\ Dantas TERTULINO, João Vitor de Oliveira GURGEL, Radan Elvis Matias de \\ OLIVEIRA*
}

Department of Animal Science, Federal Rural University of the Semi-Arido (UFERSA), Mossoró, Rio Grande do Norte, Brazil.

(Received 29 April, Accepted 26 July 2021)

\begin{abstract}
Pathoanatomical studies of diseases that affect wild animals are extremely important as appropriate measures can then be taken for the prevention and control of such diseases. We report here the case of death of a greater rhea (Rhea americana) by intestinal intussusception secondary to the ingestion of a large amount of sand. The animal was bred at the Center for Multiplication of Wild Animals of the Federal Rural University of the Semi-Arid. The animal died after presenting clinical signs of apathy, weakness, prostration, and inability to move, drink water, or eat. After death, the carcass was immediately sent for necropsy. During necropsy, intussusception was found involving the jejunum, ileum, and colon. The duodenum contained large amounts of coarse sand. The invaginated intestinal segments were reddish in color, with necrotic spots, and covered by a fibrinous exudate. Histopathological examination of the invaginated segments showed necrosis of the enterocytes, detachment of the intestinal epithelium, and the presence of inflammatory cells. The ingestion of a large amount of sand may have resulted in altered intestinal transit, contributing to the occurrence of intussusception, which resulted in ischemic alterations, intestinal necrosis, and consequent death of the animal.
\end{abstract}

Keywords: necropsy, obstruction, ratites, sablosis.

\section{INTRODUCTION}

Greater rhea (Rhea americana) are large birds that belong to the group of ratites, order Rheiforme, family Rheidae, and genus Rhea [1]. They hold significant scientific importance because of their remarkable adaptability in captivity and zootechnical value for producing meat, leather, and feathers [2].

\footnotetext{
*Corresponding author: e-mail: radan_elvis@hotmail.com
} 
Infectious or non-infectious diseases of the digestive system that affect the ratites, such as enteritis, gastric perforation, intestinal impaction, and, in rare cases, intestinal intussusception, have been increasing over the years $[3,4]$.

Among the obstructive alterations of the gastrointestinal tract, intussusception deserves special attention since it is not often reported in ratites and is not always diagnosed easily, and may be related to the death of these animals in nature or even in captivity. In this context, we present the first case report on the occurrence of intestinal intussusception secondary to the ingestion of a large amount of sand in a specimen of greater rhea.

\section{CASE PRESENTATION}

In this study, pathomorphological examination was performed on a female greater rhea (Rhea americana), approximately 1 year old, raised at the Center for Multiplication of Wild Animals, a scientific breeding facility of the Federal Rural University of the Semiarid, which is registered with the Brazilian Institute for the Environment and Renewable Natural Resources (IBAMA No. 14.78912). The rhea was raised in an enclosure, measuring $20.00 \times 10.00 \mathrm{~m}$, with a sand floor, and fed commercial ration for rhea cultures, regional fruits (papaya, banana, watermelon, and melon), green vegetables, and water ad libitum.

The patient presented clinical signs of restlessness, anorexia, weakness, drooping wings, ruffled feathers, watery diarrhea with blood, and tenesmuses. On clinical examination, the animal was found to be markedly dehydrated, with congested mucous membranes, and tenderness on abdominal palpation. Treatment was established using antibiotic therapy (enrofloxacin $5 \mathrm{mg} / \mathrm{kg}$ intramuscularly and metronidazole $25 \mathrm{mg} / \mathrm{kg}$ orally); however, the animal did not respond to treatment, and the clinical picture worsened with manifestations of apathy, weakness, prostration, and inability to move and ingest food and water, and death occurred $72 \mathrm{~h}$ after the onset of clinical manifestations.

The animal was then sent to the Laboratory of Veterinary Pathology of the Animal Sciences Department of the University Federal Rural do Semi-Árido for pathoanatomical analysis. We used the necropsy technique proposed by Rae [5], with an external examination of the animal, followed by the opening of the thoracoabdominal cavities and macroscopic visualization of the organs in situ to identify the presence of eventual alterations. The organs that presented alterations were submitted for histopathological analysis and photographic documentation.

Organ fragments, such as the liver, kidney, spleen, esophagus, proventriculus, muscular stomach, intestine, heart, and lung, were collected and fixed in 10\% buffered formalin for histopathological examination. The organ fragments were embedded in paraffin, cut to 5- $\mu \mathrm{m}$ thickness using a microtome (Leica RM2125 RT), and stained using hematoxylin-eosin [6]. Microscopic analysis of the slides was performed using a light microscope (Leica ICC50 HD) and photomicrographic documentation using the Leica software (v2.0.0. Microsystems Ltd., Heerbrugg, Switzerland). 
During necropsy, examination of the digestive tract revealed the presence of segments of the jejunum, ileum, and cecum with thickened walls, measuring approximately 10.5 $\mathrm{cm}$ in diameter, suggesting a condition compatible with intestinal obstruction (Figure 1A). Examination of the intestinal tract to determine the cause of the obstruction revealed a segment of the intestine invaginating the lumen. The invaginated intestinal segment (intussusception) was reddish in color and covered by a film of yellowishwhite fibrinous exudate with dark spots indicating necrosis (Figure 1B). Thus, a diagnosis of intestinal intussusception was established. Upon opening the duodenum, it was possible to observe a large amount of coarse sand in the intestinal contents (Figure 1C). Other findings included the presence of moderate amounts of bloody fluid in the thoraco-abdominal cavities, in addition to the congested proventriculus, gizzard, liver, kidneys, and lungs. Histological examination of the invaginated intestinal segment revealed severe necrosis of the enterocytes, associated desquamation of the intestinal epithelium, and the presence of a mixed inflammatory infiltrate in the lamina propria composed of heterophils, monocytes, macrophages, and lymphocytes and vascular congestion (Figure 1D). No histological changes were observed in the other organs.
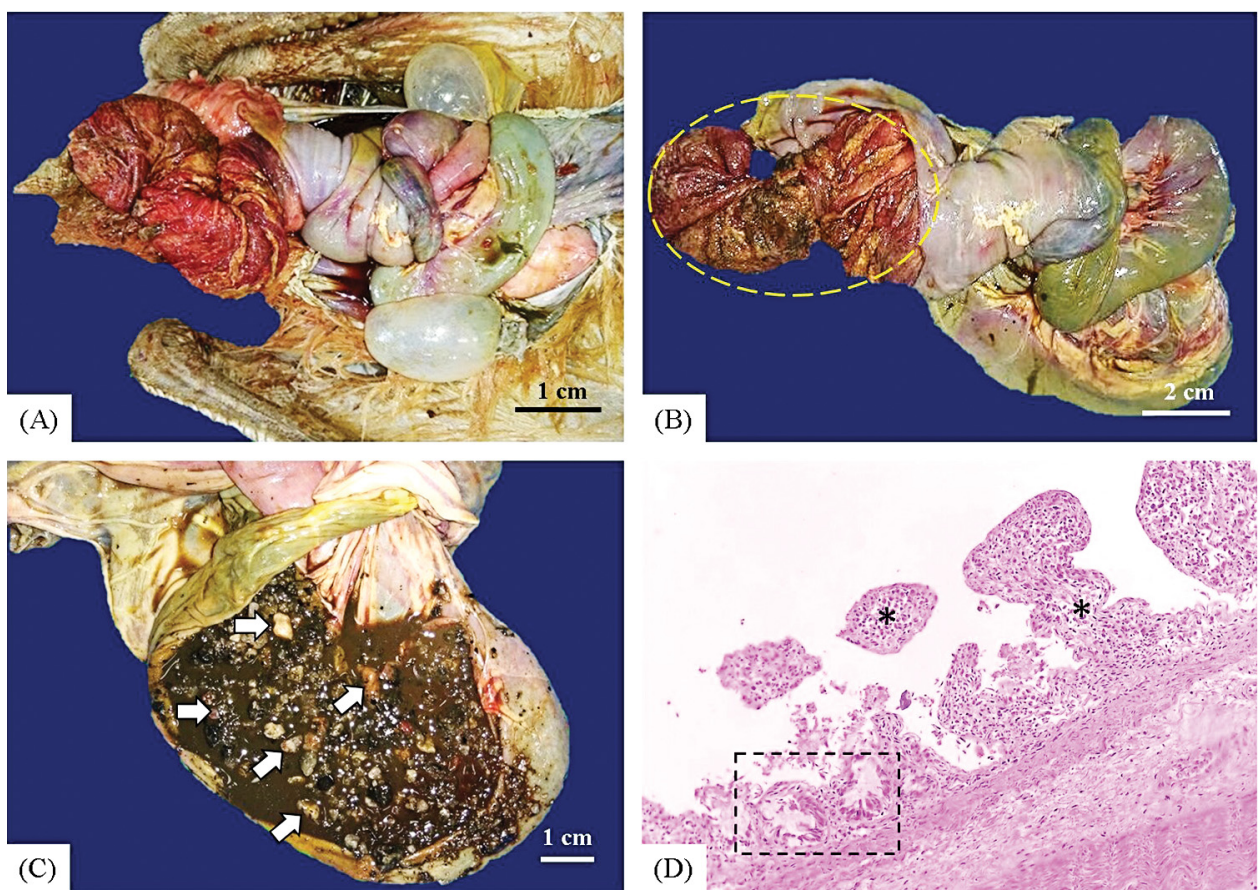

Figure 1. Macroscopic findings of intestinal intussusception in a greater rhea (Rhea americana) (A). The intussusception is thickened and reddish in color, covered by a yellowish film, with fibrinous exudate and necrotic spots (dashed circle) (B). Presence of a large amount of coarse sand mixed with intestinal contents (arrow) (C). Histopathological findings from the intestine with intussusception showing necrosis of enterocytes (dashed square), detachment of the intestinal epithelium, presence of inflammatory cells, and vascular congestion (asterisk); H\&E $=$ hematoxylin and eosin (D). 
The case of intussusception in the present report emphasizes the importance of necropsy as a diagnostic method. Post-mortem examination allows obtaining relevant information about the causes and circumstances of the animal's death and is therefore extremely important, particularly owing to the limited availability of information on the pathological processes that affect some species of wild animals with zootechnical and economic potential, especially the greater rhea.

Intestinal intussusception consists of the invagination of an intestinal segment into the lumen of the adjacent segment [7], the first of which is called intussusceptum (the branch that is invaginated), and the second is called intussuscipiens (the branch that invaginates) [8]. Intussusception is a complex disease that is of great relevance for diseases of the digestive tract that affect domestic and wild animals and requires an early diagnosis to avoid more serious complications [7,9-12].

The incidence of intussusception in the gastrointestinal tract has been reported frequently in domestic species, such as dogs and cats, as a result of gastroenteritis caused by bacterial infections [7,10]. In wild species, previous studies have described intussusception in reptiles, as in the snake Pantherophis guttatus, associated with cryptosporidiosis [9], and in a sea turtle, Chelonia mydas, associated with parasitic infestation with Octangium sp. [12].

Intussusception has also been reported in birds, such as in a tawny eagle (Aquila rapax), which was presented with intussusception in the ileo-cecum-rectal segments, as confirmed using celioscopy [13]. Rectal intussusception and cloacal wall prolapse in a hybrid falcon (Falco cherrug x Falco peregrinus) associated with bacterial enteritis [14] were also reported. In birds belonging to the ratites group, a case of intestinal intussusception was described in an ostrich (Struthio camelus) that presented necrotizing and ulcerative inflammatory changes in the intestine along with the presence of bacterial colonies [3]. Another case occurred in a 4-month-old rhea (Rhea americana) that died acutely and presented at necropsy multiple intussusceptions of the small intestine. The results of necropsy revealed that multiple intussusceptions of the intestine were associated with proventricular impaction by foreign bodies, such as fragments of sticks and stones [15].

The present report describes intussusception caused by sand accumulation in Rhea americana. The proposed pathogenesis for cases of enteric intussusception is related to increased peristaltic activity of the proximal segment of the intestine that drives the segment into the distal segment causing invagination, thus leading to development of the obstructive process. The most cases of intussusception are secondary to a prior pathological condition in the bowel that serves as the starting point, in which foreign bodies, the presence of parasites, gross and poorly digested food, and intraluminal masses or tumors stand out [16]. The major consequences of intussusception are partial or total obstruction, ischemia, necrosis, intestinal rupture, secondary tympanism, toxemia, or septic shock, which contribute to the fatal course of the condition $[17,18]$. Necropsy findings from a study in older laying hens, concluded that intussusception 
of the proventriculus is also a cause of sporadic emaciation (prominent keel, marked muscle atrophy, and generalized serous atrophy of fat), culling, and mortality, although no etiologic agent was identified [18].

In the present case, the only alteration found in the digestive tract as a predisposing factor to intussusception was the presence of a large amount of coarse sand in the lumen of the intestine, which suggests the involvement of this abnormal intraluminal content in the genesis of intussusception. Sand-related gastrointestinal disease, also known as sandy enteropathy or sablosis, is a gastrointestinal disease that has been reported in herbivorous mammals [19]. The ingestion of sand can occur from forage offered on the ground, ingestion of water from streams or weirs, and behavioral disturbances. Sand ingestion can also occur as a result of deficiency of micronutrients in the diet, such as cobalt, phosphorus, and magnesium [4,19,20]. When small amounts of sand are ingested, they generally do not result in clinical manifestations; however, if significant amounts accumulate, chronic diarrhea, weight loss, and acute abdomen may be observed $[4,20]$.

In this report, a large amount of sand was found in the intestinal lumen, which may have resulted in alterations in the intestinal transit and peristalsis, contributing to the occurrence of intussusception, resulting in ischemic alterations, intestinal necrosis, and death. This case report highlights the importance of pathoanatomical examination as it allows us to safely state the definitive diagnosis of the cause of death, thus allowing the recognition of diseases previously unknown or considered rare in wild animals. This, therefore, contributes to proper management in the captive feeding of this species.

\section{Acknowledgments}

We acknowledge the Center for Multiplication of Wild Animals (CEMAS/UFERSA) for availability of animals.

\section{Authors' contributions}

JSB, TST, ACFCS, and REMO participated in interpretation of data and drafting of the manuscript. JSB, AIBBG, IRGL, MDT, JVOG, and WLAS performed laboratory analyses (necropsy and histopathology). MFO, REMO, and JSB involved in conceptualization, methodology, interpretation, and critical revision of the manuscript. All authors read and approved the final manuscript.

\section{Declaration of conflicting interests}

The author(s) declared no potential conflicts of interest with respect to the research, authorship, and/or publication of this article. 


\section{Statement of Informed Consent}

The owner understood procedure and agrees that results related to investigation or treatment of their companion animals, could be published in Scientific Journal Acta Veterinaria-Beograd.

\section{REFERENCES}

1. Sousa RP, Monteiro HMDA, Bezerra DDO, Soares LLDS, Assis Neto AC, Rici RE, Júnior CMA, Carvalho MA: Morphogenesis of the rhea (Rhea americana) respiratory system in different embryonic and foetal stages. Pesq Vet Bras 2018, 38:154-166.

2. Costa HS, Araújo Júnior HN, Bezerra FVF, Rebouças CEV, Menezes DJA, Moura CEB, Oliveira MF: Macroscopic Anatomy and Brain Vascularization in the Greater Rhea (Rhea americana americana). Acta Sci Vet 2018, 46:1-8.

3. Bello A, Frei S, Peters M, Balkema-Buschmann A, Baumgärtner W, Wohlsein P: Spontaneous diseases in captive ratites (Struthioniformes) in northwestern Germany: A retrospective study. Plos One 2017, 12:e0173873.

4. Irfan M, Mukhtar N, Ahmad T, Munir MT: Gastric impaction: an important health and welfare issue of growing ostriches. Agric Trop Subtrop 2020, 53:161-173.

5. Rae MA: Practical avian necropsy. Semin Avian Exot Pet Med 2003, 12:62-70.

6. Tolosa EMC, Rodrigues CJ, Behmer AO, Neto AGF: Manual de técnicas para histologia normal e patológica. [Manual of techniques for normal and pathological histology]. 2nd ed. Barueri, SP: Manole; 2003, 331p.

7. MacPhail C: Gastrointestinal obstruction. Clin Tech Small Anim Pract 2002, 17:178-183.

8. Dar SH, Babaand MA, Dar KH: Prolapse of intussusception in a pup. Indian J Anim Hlth 2015, 54:63-66.

9. Bercier M, Zoll W, Rosenberg JF, Giglio R, McCoy L, Castleman WL, Johnson MD, Heard DJ: Gastric intussusceptions in a red corn snake (Pantherophis guttatus) associated with cryptosporidiosis. Case Rep Vet Med 2017, 2017:4270904.

10. Firmino MO, Frade MTS, Alves RC, Maia LA, Olinda RG, Ximenes RG, Souza AP, Dantas AFM: Intestinal intussusception secondary to enteritis caused by Pythium insidiosum in a bitch: case report. Arq Bras Med Vet Zootec 2017, 69:623-626.

11. Gibson DJ, Nemeth NM, Beaufrère H, Varga C, Eagalle T, Susta L: Captive Psittacine Birds in Ontario, Canada: a 19-Year Retrospective Study of the Causes of Morbidity and Mortality. J Comp Pathol 2019, 171:38-52.

12. Oliveira REM, Rossi S, Attademo FLN, Santoro TA, Revoredo RA, Farias DSD, Lima MA, Batista JS, Silva FJL, Gavilan SA, Oliveira MF: Colocolic intussusception associated with Octangium sp. (Digenea: Microscaphidiidae) in a green sea turtle (Chelonia mydas). J Aquatic Anim Health 2021, 32:17-23.

13. Sabater M, Huynh M, Forbes N: Ileo-ceco-rectal intussusception requiring intestinal resection and anastomosis in a Tawny Eagle (Aquila rapax). J Avian Med Surg 2015, 29:6368.

14. Cococcetta C, Binanti D, Matteucci G, Collarile T, Selleri P: Antemortem diagnosis and surgical management of a rectum intussusception and cloacal wall prolapse in a hybrid falcon (F. cherrug $\times$ F. peregrinus) associated with bacterial enteritis. J Exot Pet Med 2020, 33:10-13. 
15. Frasca Jr S, Khan MI: Multiple intussusceptions in a juvenile rhea (Rhea americana) with proventricular impaction. Avian Dis 1997, 41:475-480.

16. Valencia-Correa JJ, Botero-Velasquez JE, Salazar-Ochoa S, Montoya-Arboleda A, Jaramillo-Duque LI: Intususcepción ileotransversa por lipoma intraluminal. [leotransverse intussusception due to intraluminal lipoma]. CES Med. 2019, 33:224-230.

17. Batista JS, Olinda RG, Silva TMF, Rodrigues C.MF, Oliveira AF, Queiroz SAC, Morais SRL, Oliveira MF: Enfermidades de cutias (Dasyprocta aguti) criadas em cativeiro diagnosticadas pelo exame anatomopatológico. [Diseases of agouti (Dasyprocta aguti) raised in captivity diagnosed by pathological examination]. Pesq Vet Bras 2010, 30:497-502.

18. Reimers N, Carver D, Barnes HJ: Emaciation and sporadic mortality in older laying hens caused by intussusception of the proventriculus. Avian Dis 2019, 63:107-110.

19. Pessoa GA, Ribas ML, Novelho G, Regianini LD, Weber PR, Paese M, Lima V, Silva JH, Santos SL: Sablose em bovino no estado do Rio Grande do Sul: relato de caso. [Sablose in cattle in the state of Rio Grande do Sul: case report]. Rev Acad Ciênc Anim 2017, 15:445446.

20. Speer B: Ratite medicine and surgery. In: Proceedings of the North American Veterinary Conference. Vol. 20. Orlando, Florida: Small Animal and Exotics Edition; 2006, 1593-1597.

\section{INTUSUSCEPCIJA USLED AKUMULACIJE PESKA KOD PTICE VELIKI NANDU (RHEA AMERICANA)}

Jael Soares BATISTA, Moacir Franco de OLIVEIRA, Tiago da Silva TEÓFILO, Ana Caroline Freitas Caetano de SOUSA, Wanderson Lucas Alves dos SANTOS, Igor Renno Guimarães LOPES, Ana Indira Bezerra Barros GADELHA, Moisés Dantas TERTULINO, João Vitor de Oliveira GURGEL, Radan Elvis Matias de OLIVEIRA

Patoanatomska ispitivanja bolesti koje pogađaju divlje životinje su izuzetno važna, a potrebno je i preduzeti odgovarajuće mere radi prevencije i kontrole tih bolesti. Predmet ovog izveštaja je uginuće ptice veliki nandu (Rhea americana) usled intususcepcije creva uzrokovane gutanjem velike količine peska. Životinje su uzgajane u Centru za razmnožavanje divljih životinja FRU - stepsko područje. Smrt životinje je nastupila nakon ispoljavanja kliničkih znakova apatije, slabosti, klonulosti, nemogućnosti kretanja i neuzimanja vode i hrane. Nakon smrti, leš životinje je odmah poslat na nekropsiju. Tokom obdukcije utvrđeno je postojanje intususcepcije jejunuma, ileuma $i$ debelog creva. U duodenumu je ustanovljena velika količina krupnog peska. Invagirani segmenti creva su bili crvenkaste boje sa nekrotičnim poljima, i prekriveni fibrinoznim eksudatom. Histopatološko ispitivanje invagiranih segmenata ukazalo je na nekrozu enterocita, odvajanje crevnog epitela i prisustvo ćelija inflamacije. Gutanje velike količine peska je moglo da ima za posledicu promene u prohodnosti creva, što je doprinelo stvaranju intususcepcije, koja je dalje uzrokovala ishemijske promene, nekrozu i na konačno uginuće životinje. 